\title{
Drought Stresses on Seed Germination and Early Growth of Maize and Sorghum
}

\author{
Mariana S. Queiroz ${ }^{1}$, Carlos E. S. Oliveira ${ }^{1}$, Fábio Steiner ${ }^{1}$, Alan M. Zuffo ${ }^{2}$, Tiago Zoz ${ }^{1}$, \\ Eduardo P. Vendruscolo ${ }^{1}$, Mennes V. Silva ${ }^{1}$, Bruna F. F. R. Mello ${ }^{1}$, Rogério C. Cabral ${ }^{1} \&$ Flavio T. Menis ${ }^{1}$ \\ ${ }^{1}$ Department of Crop Science, State University of Mato Grosso do Sul, Cassilândia, MS, Brazil \\ ${ }^{2}$ Department of Agronomy, Federal University of Mato Grosso do Sul, Chapadão do Sul, MS, Brazil \\ Correspondence: Fábio Steiner, Department of Crop Science, State University of Mato Grosso do Sul, Cassilândia, \\ MS, Brazil. Tel: 55-673-596-7600. E-mail: steiner@uems.br
}

Received: October 30, $2018 \quad$ Accepted: November 10, $2018 \quad$ Online Published: January 15, 2019

doi:10.5539/jas.v11n2p310 URL: https://doi.org/10.5539/jas.v11n2p310

The research is financed by Coordination of Improvement of Higher Education Personnel-CAPES.

\begin{abstract}
Seeds of maize (Zea mays L.) and sorghum [Sorghum bicolor (L.) Moench.] were submitted to different osmotic potential levels induced by polyethylene glycol (PEG) with the objective of evaluating the effects of drought stress on seed germination and early seedling growth. Seeds were arranged in paper rolls and soaked in PEG solutions prepared with osmotic potentials 0.0 (control), $-0.2,-0.4$, and $-0.8 \mathrm{MPa}$ and kept into a seed germinator, at $25{ }^{\circ} \mathrm{C}$ for 18 days. A completely randomized design in a $2 \times 4$ factorial scheme with four replications of 50 seeds each was used. The results showed that by increasing of the osmotic potential level, germinated seed number, germination rate index, root and shoot length, shoot and root dry matter, and seedling vigor index (SVI) decreased, while mean germination time (MGT) and root: shoot ratio (RSR) increased in both crops. Additionally, the maize was more susceptible than sorghum to drought stress, with germination response declining more rapidly with decreasing osmotic potential. Sorghum crop tolerates water stress of up to $-0.2 \mathrm{MPa}$, without reducing germination of the seeds; however, the growth of shoots and roots are inhibited. Drought stress limits the process of seed germination and early growth of maize seedlings.
\end{abstract}

Keywords: Zea mays L., Sorghum bicolor (L.) Moench, osmotic potential, PEG, water stress

\section{Introduction}

Maize (Zea mays L.) and sorghum [Sorghum bicolor (L.) Moench.] are two of the most important cereal crops in the world due to their use for food, animal feed/forage, for ethanol production and other industrial products. Drought is one of the most critical environmental factors that limit growth and yield of maize and sorghum crops in Brazil and other areas of the world. The relative decrease in the potential maximum crop yields (i.e., yields under ideal conditions) associated with drought can reach 70\% (Bray et al., 2000). Therefore, to ensure the food supply for a growing world population, studies that aim to mitigate the detrimental effects of drought and identify crop species with higher tolerance are extremely important for agricultural research.

Seed germination and seedling establishment are potentially the most critical stages for water stress (Ahmad et al., 2009). Water availability and movement into the seeds are very important to promote germination, initial root growing, shoot elongation and therefore at the establishment of a uniform stand. The germination starts with seed imbibition as result of water uptake. This process occurs due to the distinct levels of osmotic potential between the dry seed and water in the substrate of germination. However, the seeds should reach a satisfactory hydration level to allow reactivation of seed metabolic processes, which depends on the chemical composition and tegument permeability (Marcos-Filho, 2005). In general, seed water content of cereal crops must reach at least 35 to $45 \%$ of seed dry mass to occur the germination process. The highly negative osmotic potential may affect the seeds water uptake, making germination not possible (Meneses et al., 2011). The most common responses of plants to the reduction of osmotic potential are a delay in initial germination and a reduction in the rate and total germination (Oliveira \& Gomes-Filho, 2009; Ahmad et al., 2009; Gordin et al., 2015). 
An alternative method to field experiments related to drought stress is to induce stress using polyethylene glycol (PEG) under controlled laboratory conditions. Polyethylene glycol with molecular mass of 6000 or more are non-penetrable and non-toxic osmotic substance which can be used to lower the water potential of the germination environmental and it has been used to simulate controlled drought stress in nutrient solution cultures (Zhu et al., 2006). Many studies on plant responses to drought stress induced by PEG solutions with regard to seed germination and seedling growth have been recently reported, including studies of crops, common bean (Machado-Neto et al., 2006), soybean (Teixeira et al., 2008), sunflower (Ahmad et al., 2009), sorghum (Oliveira \& Gomes-Filho, 2009), maize (Khodarahmpour, 2011), and cotton (Meneses et al., 2011).

Sorghum is recognized for its moderate tolerance to drought stress (Tabosa et al., 2002) and may be considered as an alternative to cropping in low rainfall regions. Identification and understanding the mechanisms of drought tolerance in sorghum have been major goals of plant physiologists and breeders which includes prolific root system, ability to maintain stomatal opening at low levels of leaf water potential and high osmotic adjustment (Rajendran et al., 2011; Tsago et al., 2014). However, information about this moderate tolerance to drought during the seed germination and seedling establishment stages are still incipient and inconclusive. Drought stress affects almost every developmental stage of the plant. However, damaging effects of this stress was more noted when it coincided with various growth stages such as germination, establishment, and flowering (Khayatnezhad et al., 2010; Tsago et al., 2014).

Maize is relatively susceptible to drought. Indeed, Khodarahmpour (2011) showed that the osmotic potential of $-1.2 \mathrm{MPa}$ reduced the seed germination and shoot length of maize seedlings at 71 and $90 \%$, respectively, when compared to the control $(0 \mathrm{MPa})$. However, Kappes et al. (2010) found that the germination of different maize hybrids ranged from 36 to $65 \%$ at the osmotic potential of $-1.2 \mathrm{MPa}$. These contradictory results indicate that there is a distinct response between the different genotypes or hybrids; therefore, justifying the need for conducting more research to investigate the tolerance of maize to drought.

This research was carried out to investigate the effects of drought stresses induced by polyethylene glycol (PEG) on seed germination and early seedling growth of maize (Zea mays L.) and sorghum [Sorghum bicolor (L.) Moench.].

\section{Method}

\subsection{Plant Material and Treatments}

Seeds of maize (Zea mays L. hybrid DKB 290 PRO) and sorghum [Sorghum bicolor (L.) Moench., hybrid Dow 1G244] were surface sterilized for 5 minutes with sodium hypochlorite solution $(2 \%, \mathrm{v} / \mathrm{v})$. Afterward, seeds were subjected to four osmotic potential levels $[0.0$ (control); $-0.2 ;-0.4$; and $-0.8 \mathrm{MPa}]$ induced by different concentrations of polyethylene glycol 6000 (PEG 6000). The PEG-6000 concentrations required to obtain these values were determined by using the equation of Michel and Kaufmann (1973):

$$
\Psi_{\mathrm{s}}=\left[-\left(1.18 \times 10^{-2}\right) \cdot \mathrm{C}-\left(1.18 \times 10^{-4}\right) \cdot \mathrm{C}^{2}+\left(2.67 \times 10^{-4}\right) \cdot \mathrm{CT}+\left(8.39 \times 10^{-7}\right) \cdot \mathrm{C}^{2} \mathrm{~T}\right] / 10
$$

where, $\Psi_{\mathrm{s}}=$ osmotic potential $(\mathrm{MPa}) ; \mathrm{C}=$ concentration $\left(\mathrm{g} \mathrm{L}^{-1} \mathrm{PEG}-6000\right) ; \mathrm{T}=$ temperature $\left({ }^{\circ} \mathrm{C}\right)$. As control, a solution with osmotic potential $\Psi \mathrm{s}=0.0 \mathrm{MPa}$ was used. The treatments were arranged in a completely randomized design, in a factorial arrangement, with two plant species (maize and sorghum) and four osmotic potentials $(0.0 ;-0.2 ;-0.4$; and $-0.8 \mathrm{MPa})$, with four replicates.

\subsection{Germination Conditions}

Four replicates of 50 seeds from each species were evenly distributed between two sheets of germination paper $\left(\right.$ Germitest $\left.{ }^{\mathbb{B}}\right)$, properly moistened with different PEG solutions, in a volume equivalent to 2.5 times the mass of dry paper, and made into rolls. The rolls were then packaged into plastic bags to prevent evaporation and maintain the relative humidity close to $100 \%$. Germination was carried out in a germinator under a constant temperature of $25{ }^{\circ} \mathrm{C}\left(24-26^{\circ} \mathrm{C}\right)$ in the light for 18 days. Seeds were considered germinated when radicle was longer than $5.0 \mathrm{~mm}$. Germinated seeds were recorded every $24 \mathrm{~h}$ for 18 days.

\subsection{Measurements of Germination and Seedling Growth}

The germination capacity (GC), germination rate index (GRI), mean germination time (MGT), mean germination rate (MGR) and early growth of maize and sorghum seedlings were measured. The Equations 2-5 and the parameters therein were employed to express the seed germination and vigor index of seedlings.

$$
\mathrm{GC}(\%)=\mathrm{S}_{\mathrm{NG}} / \mathrm{S}_{\mathrm{N} 0} \times 100
$$

where, $\mathrm{GC}$ is germination capacity, $\mathrm{S}_{\mathrm{NG}}$ is the number of germinated seeds, and $\mathrm{S}_{\mathrm{N} 0}$ is the number of experimental seeds with viability (50 seeds). 


$$
\text { GRI }=\Sigma\left(n_{\mathrm{i}} / \mathrm{t}_{\mathrm{i}}\right)
$$

where, GRI is the germination rate index ( seed day $\left.{ }^{-1}\right), n_{i}$ is the number of germinated seeds on a given day, and $t_{i}$ is the time in days from the sowing day (Maguire, 1962).

$$
\operatorname{MGT}=\left(\sum \mathrm{n}_{\mathrm{i}} \mathrm{t}_{\mathrm{i}}\right) / \Sigma \mathrm{n}_{\mathrm{i}}
$$

where, MGT is the mean germination time (day), $n_{i}$ is the number of germinated seeds on a given day, and $t_{i}$ is the time in days from the sowing day (Labouriau, 1983a).

$$
\mathrm{SVI}=\mathrm{SL} \times \Sigma\left(\mathrm{n}_{\mathrm{i}} / \mathrm{t}_{\mathrm{i}}\right)
$$

where, SVI is seedling vigor index, SL is the shoot length, $\mathrm{n}_{\mathrm{i}}$ is the number of germinated seeds on a given day, and $t_{i}$ is the time in days from the sowing day (Zhang et al., 2007).

The shoot and primary root length were measured in 20 normal seedlings randomly obtained after count of the total germination $\left(18^{\text {th }}\right.$ day) using meter scale, and the results were expressed in millimeter (mm). The shoot dry matter (SDM, in mg) and root dry matter (RDM, in mg) were recorded after oven drying at $65{ }^{\circ} \mathrm{C}$ for $72 \mathrm{~h}$. To determine root: shoot ratio (RSR), root dry matter obtained was divided by the shoot dry matter. To determine root: shoot ratio (RSR), root dry matter obtained were divided by the shoot dry matter. The data of total dry matter production were recorded for each crop at each stress treatment and used to calculate the drought tolerance indices. The drought tolerance index was calculated using the following equation:

$$
\mathrm{YSI}=\mathrm{YS} / \mathrm{YC}
$$

where, YSI is the yield stability index, YS and YC are the total dry matter yield (mg per seedling) under drought stress and non-stress conditions (control), respectively (Bouslama \& Schapaugh, 1984).

\subsection{Statistical Analyses}

The normality of data was previously tested by the Kolmogorov-Smirnov test and then data were submitted to analysis of variance (ANOVA), and means of plant species and osmotic potentials were compared by the $\mathrm{F}$ and Tukey test, respectively, both at the 0.05 level of confidence. For statistical analysis, the data expressed in percentage were previously transformed into $\arcsin (\mathrm{x} / 100)^{0.5}$. The analyses were performed using Sisvar software, version 5.6, for Windows (Statistical Analysis Software, UFLA, Lavras, MG, BRA).

\section{Results and Discussion}

The results of the analysis of variance showed significant effects $(\mathrm{P}<0.05)$ for the main effects of plant species and osmotic potential levels, as well as for interaction, for the majority of the traits measured (Table 1). The significant interaction between the main effects of crops and osmotic potentials for most of the evaluated traits indicates that plant species have a distinct response when exposed to different drought levels. Such inference may be due to seed size, the chemical composition of reserves, tegument permeability, hydration duration and activation of enzymatic reactions.

Table 1. Summary of the analysis of variance for the measurements of germination, vigor index and growth inhibition of maize and sorghum seedlings under drought stress

\begin{tabular}{lllllllllll}
\hline \multirow{2}{*}{ Causes of variation } & \multicolumn{1}{c}{ Probability $>$ F } & \multicolumn{1}{c}{$c$} \\
\cline { 2 - 11 } & GC & GRI & MGT & SVI & SL & RL & SDM & RDM & TDM & RSR \\
\hline Species (S) & $<0.000$ & $<0.000$ & $<0.000$ & $<0.000$ & $<0.000$ & 0.014 & $<0.000$ & 0.281 & $<0.000$ & $<0.000$ \\
PEG (P) & $<0.000$ & $<0.000$ & $<0.000$ & $<0.000$ & $<0.000$ & $<0.000$ & $<0.000$ & $<0.000$ & $<0.000$ & $<0.000$ \\
S $\times$ P & $<0.000$ & $<0.000$ & $<0.000$ & $<0.000$ & $<0.000$ & 0.927 & $<0.000$ & 0.087 & $<0.000$ & 0.005 \\
CV $(\%)$ & 3.18 & 2.50 & 1.98 & 3.93 & 8.59 & 9.88 & 7.42 & 8.27 & 7.95 & 8.34 \\
\hline
\end{tabular}

Note. GC: germination capacity. GRI: germination rate index. MGT: mean germination time. SVI: seedling vigor index. SL: Shoot length. RL: radicle length. SDM: shoot dry matter. RDM: root dry matter. TDM: Total dry matter. RSR: root: shoot ratio.

\subsection{Effect of Drought Stress on Seed Germination Process}

The germination percentage in the control treatment were higher than the standard values (i.e., $85 \%$ and $80 \%$ for maize and sorghum) for commercially available maize and sorghum seeds in Brazil (MAPA, 2013), indicating that the seeds used in this study were of high physiological quality. 
The germination response of maize and sorghum seeds was significantly affected by drought stress induced by PEG solutions. When the seeds were exposed to highly negative osmotic potentials, germination capacity was drastically reduced. Germination percentage was reduced from $93 \%$ and $97 \%$ in the control treatment to a minimum of $25 \%$ and $58 \%$ when the seeds of maize and sorghum were exposed to lower osmotic potential (-0.8 $\mathrm{MPa}$ ), respectively (Figure 1A). These results show that the $-0.8 \mathrm{MPa}$ osmotic potential resulted in reduction on GC of maize and sorghum seeds of $73 \%$ and $40 \%$, respectively. Similar results were reported by Khodarahmpour (2011), who found that the $-1.2 \mathrm{MPa}$ osmotic potential reduced the germination rate of maize at $71 \%$ compared to the control treatment ( $0 \mathrm{MPa})$. Kappes et al. (2010) found that the osmotic potential of $-1.2 \mathrm{MPa}$ reduced the germination of four maize hybrids of 32 to $63 \%$ when compared to the control. Pias et al. (2017) measured that the $-0.8 \mathrm{MPa}$ osmotic potential completely inhibited the formation of normal seedlings in all four maize hybrids.

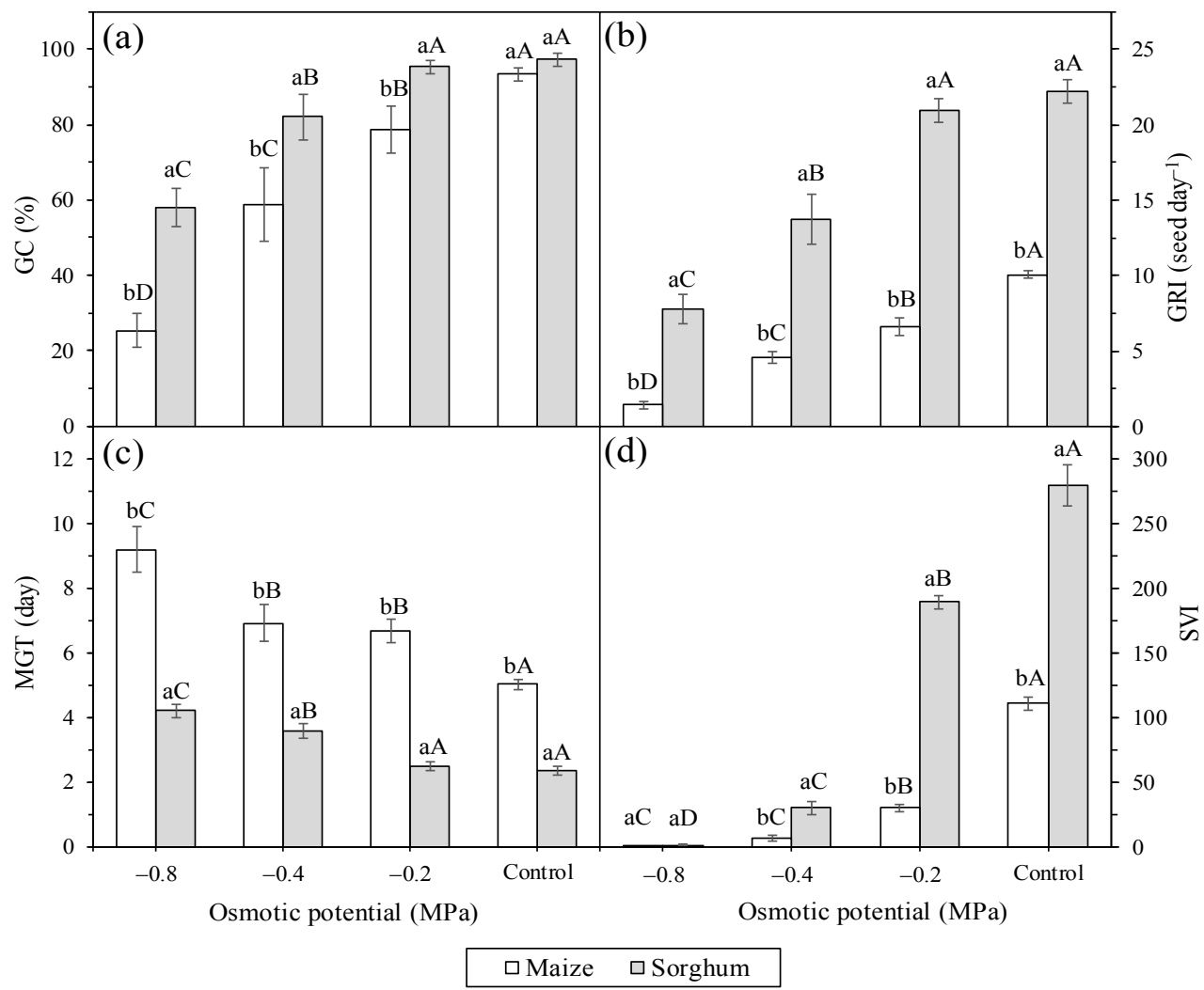

Figure 1. Effects of drought stress induced by polyethylene glycol on germination capacity (GC, in A), germination rate index (GRI, in B), mean germination time (MGT, in C) and seedling vigor index (SVI, in D) of maize and sorghum. Bars followed by the same lowercase letters, between the plant species or same uppercase letters, for the osmotic potential levels are not significantly different by $\mathrm{F}$ and Tukey test, respectively, both at the 0.05 level of confidence. Data refer to mean values $(n=4) \pm$ standard error

The germination rate index (GRI) of maize seeds ranged from 1.4 to 10.1 seed day $^{-1}$ and was drastically reduced with the rise of osmotic potential levels (Figure 1B). For sorghum seeds, the GRI ranged from 7.8 to 22.2 seed $\mathrm{day}^{-1}$, and was significantly greater when seeds were exposed to the osmotic potential of 0.0 (control) and -0.2 $\mathrm{MPa}$, and lower under the osmotic potential of $-0.8 \mathrm{MPa}$ (Figure 1B). This increase in the index of germination rate was due to the lower capacity of water uptake by the seeds with highly negative osmotic potential. Oliveira and Gomes-Filho (2009) investigated the effect of different osmotic potentials (0 to $-0.8 \mathrm{MPa})$ on the germination of sorghum seeds, and also found that germination rate index and germination percentage, as well as the amount of water absorbed by seeds, were considerably lowered with the rise of the osmotic potential level. Drought stress affects the starch synthesis reactions and energy production process (adenosine triphosphate-ATP) through respiration, resulting in reduced of germination rate index (Figure 1B) and germination percentage (Figure 1A) and thus in the low index of seedling vigor (Figure 1D). 
The mean germination time (MGT) was delayed by the lower osmotic potential (-0.8 MPa) in 2 days ( 2 to 4 days) and 4 days ( 5 to 9 days) compared with control treatments for the seeds of maize and sorghum, respectively (Figure 1C). MGT is defined as a measure of the rate and time-spread of germination (Marcos-Filho, 2005). A delay in the average time to germination may be disadvantageous for successful establishment, since the delayed germination leaving the seeds more vulnerable to attack from predators (pests and pathogens) and, therefore, compromise the establishment of a uniform stand.

The delay in germination was due to the fact of the highly negative osmotic potential affect the water uptake of the seeds, which is the first step to occur germination process (i.e., imbibition). According to Marcos-Filho (2005), it is necessary that the seeds reach an adequate level of hydration during the imbibition phase, to occur reactivation of seed metabolic processes and growth of embryonic axis. Seeds subjected to severe drought stress require more time to adjust the internal osmotic potential in accordance with the external environment (Santarém et al., 1996). Meneses et al. (2011) reported that highly negative osmotic potential may affect the seeds water uptake, making germination not possible. Additionally, the osmotic potential of the external medium can affect the enzymatic reactions in the seed, therefore, the delay in germination is due to delay of enzymatic reactions (Hadas, 1976), caused by the break of the imbibition period. The most common responses of plants to the reduction of osmotic potential are a delay in initial germination and a reduction in the rate and total germination (Teixeira et al., 2008; Oliveira \& Gomes-Filho, 2009; Ahmad et al., 2009; Gordin et al., 2015). The result of these changes is an unevenness in the germination process and stand establishment.

Sorghum showed higher germination percentage, germination rate index, seedling vigor index and lower mean germination time in practically all levels of osmotic potential compared to the maize crop (Figure 1). During the seed germination phase, the osmotic potential of $-0.2 \mathrm{MPa}$ was not a limiting factor for sorghum crop by present germination percentage (Figure 1A), germination rate index (Figure 1B) and mean germination time (Figure 1C) similar to the control treatment $(0.0 \mathrm{MPa})$. In turn, the maize crop showed reductions in these variables in all levels of osmotic potential, resulting in seedlings with low vigor index (Figure 1D). These results indicate that sorghum is more tolerant than maize to drought stress. These results confirm those reported by Santos et al. (2014), which found the sorghum by present the higher photosynthetic rates and photoassimilates partition showed the best ecophysiological performance under water restriction compared to the maize and signal grass (Brachiaria decumbens Stapf). Germination is a critical stage of the plant life and resistance against drought during the germination makes a uniform plant stand.

Seeds of distinct species have distinct levels of starch and other food storage, which may be one factor with great influence on germination and seedling growth rate. Germination may be dependent on the capacity of the seed to utilize reserves more efficiently, by mobilization of seed reserves for germination traits (Sikder et al., 2009). Therefore, the use of species or genotypes with higher seed metabolic efficiency is a desirable character under drought conditions when emergence and establishment are delayed due to insufficient soil moisture.

\subsection{Effect of Drought Stress on Early Seedling Growth}

The growth of maize and sorghum seedlings was significantly affected by drought stress induced by PEG solutions (Figure 2). There was a decrease in shoot and root-related traits with the rise of osmotic potential levels. The maximum value for shoot length, radicle length, shoot, root, and the total dry matter was observed in control $(0.0 \mathrm{MPa})$ and the minimum value was observed in osmotic potential of $-0.8 \mathrm{MPa}$ (Figure 2$)$. The highest values obtained for the length and dry matter of seedlings in the control treatment is associated with higher germination rate index (Figure 1B) and less time to occur germination (Figure 1C). Seedlings that emerge more quickly have higher time to develop compared to those that germinate later, and may have increased in seedling length and dry matter accumulation. Indeed, Khodarahmpour (2011) found that the osmotic potential of -1.2 MPa delayed the process of seed germination of maize resulting in lower height seedlings compared to control treatment.

The osmotic potential of $-0.8 \mathrm{MPa}$ resulted in the reduction of shoot length of maize and sorghum seedlings of $99.1 \%$ (110 to $1 \mathrm{~mm}$ ) and $98.4 \%$ (126 to $2 \mathrm{~mm}$ ), respectively compared to control (Figure 2A). This decrease in the growth rate of the seedlings could be due to a reduction in one or both of the primary cellular growth parameters: wall extensibility and cell turgor. In water stress conditions, seedling growth is affected due to the reduction of water uptake by the plants and lower cell turgor pressure (Taiz \& Zeiger, 2009). Indeed, Li et al. (2001) reported a growth rate of seedlings from $27.8 \mathrm{~mm} \mathrm{day}^{-1}$ under well-watered conditions, whereas under drought stress conditions this growth rate was only $16.1 \mathrm{~mm}_{\text {day }}{ }^{-1}$.

According to Silva et al. (2007), one of the first processes affected in response to decreased water availability is cell expansion, highly dependent process turgidity of the plants. As a result of these effects, there is a reduction in dry matter production of plants (Figures $2 \mathrm{C}$ and 2D). The reduced of leaf productions occurs as a defense 
reaction of plants to drought, reducing transpiration rate and therefore, the water loss to the atmosphere. Drought stress has been found to limit growth in several agricultural crops such common bean (Machado-Neto et al., 2006), soybean (Teixeira et al., 2008), sunflower (Ahmad et al., 2009), sorghum (Oliveira \& Gomes-Filho, 2009), maize (Khodarahmpour, 2011) and cotton (Meneses et al., 2011). Therefore, the response characters of plants exposed to drought stress have become a crucial environmental research topic in drought-prone regions.

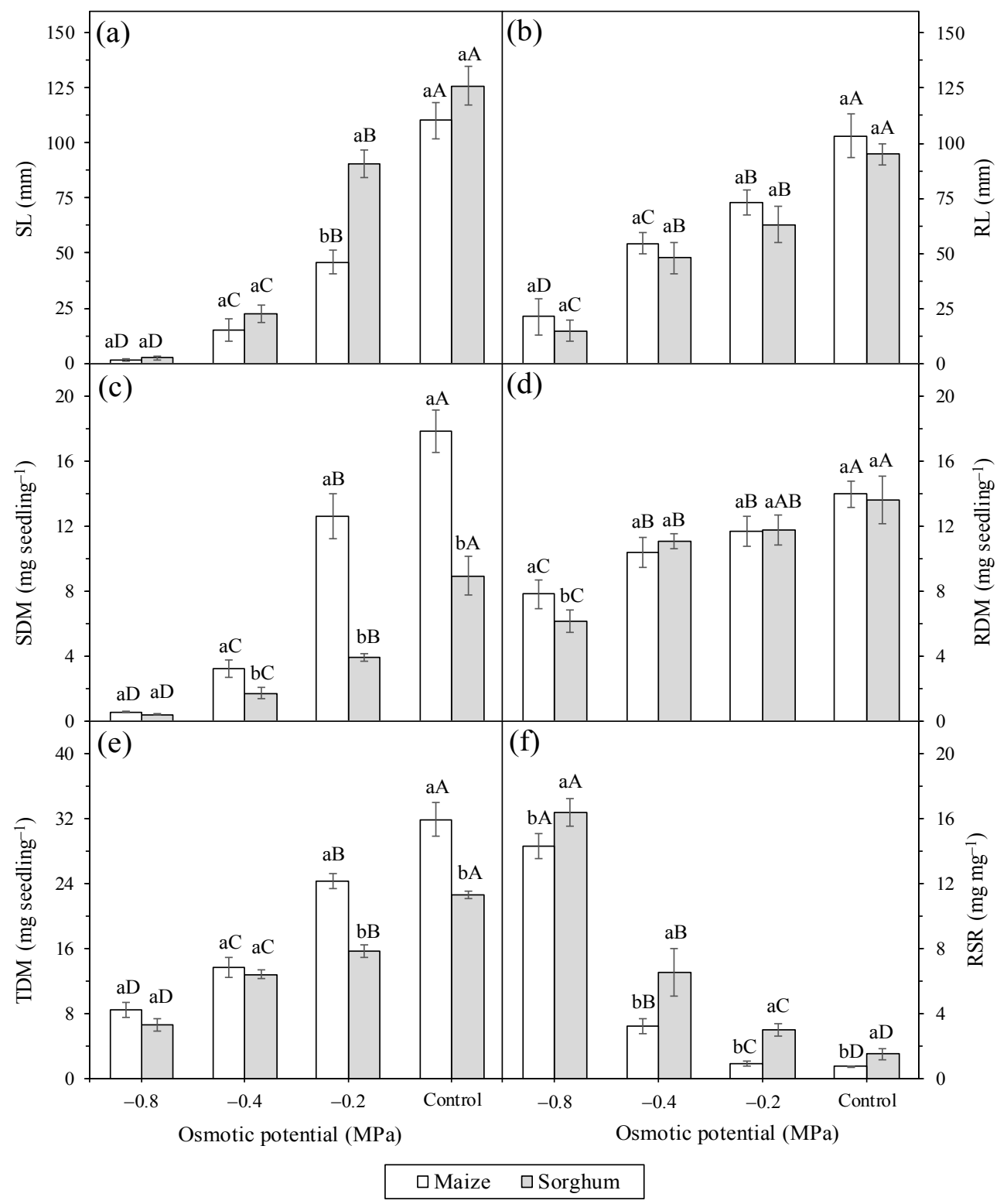

Figure 2. Effects of drought stress induced by polyethylene glycol on shoot length (SL, in A), radicle length (RL, in B), shoot dry matter (SDM, in C), root dry matter (RDM, in D), total dry matter (TDM, in E) and root: shoot ratio (RSR, in F) of maize (white bars) and sorghum (gray bars) seedlings. Bars followed by the same lowercase letters, between the plant species or same uppercase letters, for the osmotic potential levels are not significantly different by $F$ and Tukey test, respectively, both at the 0.05 level of confidence. Data refer to mean values $(n=4)$ \pm standard error

The root: shoot ratio (RSR) is one of several ratios, which give estimates of the distribution of dry matter between the different plant organs. It is a measure of the distribution of dry matter between the root and the shoot systems and it is a good indicator for effects on root and shoot dry matter (Boutraa et al., 2010). The results showed that RSR was increased with the rise of osmotic potential levels (Figure 2F). This suggests that shoot 
growth was affected more than the root system under drought stress. Such increase in RSR indicates that the proportion of dry matter allocated to shoots was decreased compared to the roots. Studies have shown that shoot is more likely to be affected by water stress than other traits, as reported by Boutraa et al. (2010) for wheat seedlings. Assimilate partitioning is a complicated process that can be controlled simultaneously by sources and sinks. In general, plants exposed to high osmotic potential levels often partition photosynthate occurs preferentially to the roots, thereby maintaining a balance between processes required in roots (e.g., water and nutrient uptake) and those required in shoots (e.g., photosynthesis).

Sorghum showed higher RSR compared the maize seedlings at all levels of osmotic potential (Figure 2F), indicating that the dry matter allocated to the roots was increased compared to that of the shoot of sorghum seedlings. During the establishment period of plants, the allocation of dry matter to the roots seems to be a protection mechanism for the crop tolerate a water restriction condition. Therefore, results presented here suggest that sorghum is a species more tolerant than maize to the negative effects of drought during the seedling establishment stage, confirming the results reported by Tabosa et al. (2002).

The highest dry matter production of shoots was observed for maize seedlings in the majority of osmotic potential levels (Figure 2C). This increase in shoot dry matter of maize may be related to the intrinsic characteristics of the species and size of seeds. The mass of one thousand seeds of maize hybrid DKB 290 PRO is $290 \mathrm{~g}$, while the weight of a thousand seeds of sorghum hybrid Dow 1G244 is $15 \mathrm{~g}$. Large sized seeds have a greater amount of carbohydrates and other nutrients, and consequently more reserves to be translocated to the shoot growth when compared to the small-sized seeds (Shahi et al., 2015). In addition, different size of seeds having different levels of starch and other food storage may be one factor which influences the expression of germination and growth of the plants.

The yield stability index (YSI) of maize and sorghum seedlings ranged from 0.26 to 0.76 and 0.29 to 0.69 , respectively, and was drastically reduced with the rise of osmotic potential levels (Figure 3). The YSI was suggested by Bouslama and Schapaugh (1984) in order to evaluate the stability of crops or genotypes in both stress and non-stress conditions and has been considered a good drought tolerance index. Sorghum had higher yield stability index compared to maize when subjected to an osmotic potential of $-0.4 \mathrm{MPa}$. This result suggests that the sorghum crop can tolerate conditions more severe water stress compared to maize.

In general, the results presented here indicate that the germination process of sorghum seeds is not adversely affected by the osmotic potential of $-0.2 \mathrm{MPa}$; however, the same water stress condition reduces the initial growth of the seedlings. For maize crop, all traits of seed germination and seedling growth were affected by water stress.

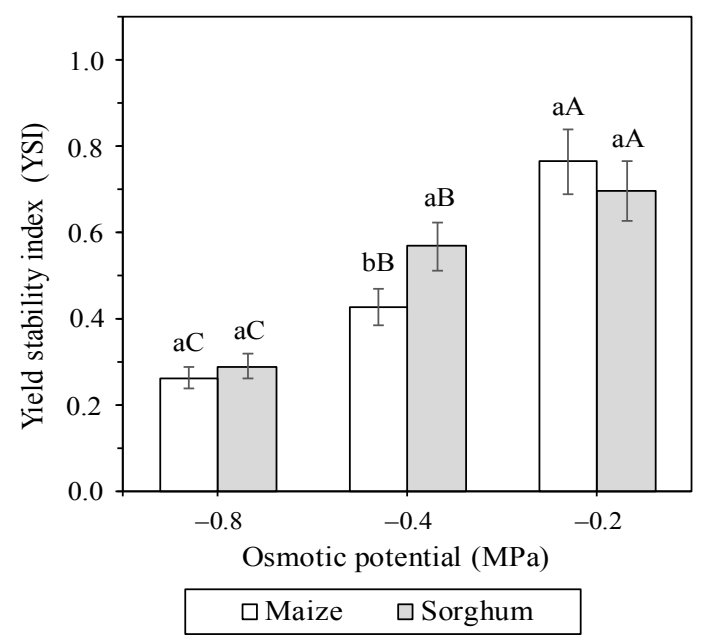

Figure 3. Effects of drought stress induced by polyethylene glycol on the yield stability index (YSI) of maize (white bars) and sorghum (gray bars) seedlings. Bars followed by the same lowercase letters, between the plant species or same uppercase letters, for the osmotic potential levels are not significantly different by F and Tukey test, respectively, both at the 0.05 level of confidence. Data refer to mean values $(n=4) \pm$ standard error 


\section{Conclusions}

Maize is more susceptible than sorghum to drought stress, with germination response declining more rapidly with increasing osmotic potential. Sorghum crop tolerates water stress of up to $-0.2 \mathrm{MPa}$, without reducing germination of the seeds; however, the growth of shoots and roots are inhibited. Drought stress limits the process of seed germination and early growth of maize seedlings.

\section{References}

Ahmad, S., Ahmad, R., Ashraf, M. Y., Ashraf, M., \& Waraich, E. A. (2009). Sunflower (Helianthus annuus L.) response to drought stress at germination and seedling growth stages. Pakistan Journal of Botany, 41(2), 647-654.

Bouslama, M., \& Schapaugh, W. T. (1984). Stress tolerance in soybean. Part 1: Evaluation of three screening techniques for heat and drought tolerance. Crop Science, 24(4), 933-937. https://doi.org/10.2135/ cropsci1984.0011183X002400050026x

Boutraa, T., Akhkha, A., Al-Shoaibi, A. A., \& Alhejeli, A. M. (2010). Effect of water stress on growth and water use efficiency (WUE) of some wheat cultivars (Triticum durum) grown in Saudi Arabia. Journal of Taibah University for Science, 3(1), 39-48. https://doi.org/10.1016/S1658-3655(12)60019-3

Bray, E. A., Bailey-Serres, J., \& Weretilnyk, E. (2000). Responses to abiotic stresses. In B. B. Buchanan, W. Gruissem, \& R. L. Jones (Eds.), Biochemistry and Molecular Biology of Plants (pp. 1158-1203). American Society of Plant Physiologists, Rockville.

Gordin, C. R. B., Scalon, S. P. Q., \& Masetto, T. E. (2015). Disponibilidade hídrica do substrato e teor de água da semente na germinação de niger. Pesquisa Agropecuária Tropical, 45(3), 312-318. https://doi.org/10.159 0/1983-40632015v4535337

Hadas, A. (1976). Water uptake \& germination of Leguminous seeds under changing external water potential in osmotic solutions. Journal of Experimental Botany, 27(6), 480-489. https://doi.org/10.1093/jxb/27.3.480

Kappes, C., Andrade, J. A. C., Haga, K. I., Ferreira, J. P., \& Arf, M. V. (2010). Germinação, vigor de sementes e crescimento de plântulas de milho sob condições de déficit hídrico. Scientia Agraria, 11(2), 125-134. https://doi.org/10.5380/rsa.v11i2.16464

Khayatnezhad, M., Gholamin, R., Jamaatie-Somarin. S. H., \& Zabihi-Mahmoodabad, R. (2010). Effects of PEG stress on corn cultivars (Zea mays L.) at germination stage. World Applied Science Journal, 11(5), 504-506.

Khodarahmpour, Z. (2011). Effect of drought stress induced by polyethylene glycol (PEG) on germination indices in corn (Zea mays L.) hybrids. African Journal of Biotechnology, 10(79), 18222-18227. https://doi.org/10.5897/AJB11.2639

Labouriau, L. G. (1983). A germinação de sementes (p. 174). Washington: Organização dos Estados Americanos.

Li, F. L., Bao, W. K., \& Wu, N. (2011). Morphological, anatomical and physiological responses of Campylotropis polyantha (Franch.) Schindl. seedlings to progressive water stress. Science Horticulturae, 127(4), 436-443. https://doi.org/10.1016/j.scienta.2010.10.017

Machado-Neto, N. B., Custódio, C. C., Castilho, C., Costa, P. R., \& Doná, F. L. (2006). Deficiência hídrica induzida por diferentes agentes osmóticos na germinação e vigor de sementes de feijão. Revista Brasileira de Sementes, 28(1), 142-148. https://doi.org/10.1590/S0101-31222006000100020

Maguire, J. D. (1962). Speed of germination-aid in selection and evaluation for seedling emergence and vigor. Crop Science, 2, 176-177. https://doi.org/10.2135/cropsci1962.0011183X000200020033x

MAPA (Ministério da Agricultura, Pecuária e Abastecimento). (2013). Padrões para produção e comercialização de sementes de milho (Zea mays L.) e sorgo (Sorghum bicolor L.). Instrução Normativa 45, de 17 de Setembro de 2013. Diário Oficial da União, sec.1, de 20/09/2013.

Marcos-Filho, J. (2005). Fisiologia de sementes de plantas cultivadas (p. 495). Piracicaba: FEALQ.

Meneses, C. H. S. G., Bruno, R. L. A., Fernandes, P. D., Pereira, W. E., Lima, L. H. G. M., Lima, M. M. A., \& Vidal, M. S. (2011). Germination of cotton cultivar seeds under water stress induced by polyethyleneglycol-6000. Scientia Agricola, 68(2), 131-138. https://doi.org/10.1590/S0103-901620110002 00001

Michel, B. E., \& Kaufmann, M. R. (1973). The osmotic potential of polyethylene glycol 6000. Plant Physiology, 51(5), 914-916. https://doi.org/10.1104/pp.51.5.914 
Oliveira, A. B., \& Gomes-Filho, E. (2009). Germinação e vigor de sementes de sorgo forrageiro sob estresse hídrico e salino. Revista Brasileira de Sementes, 31(3), 48-56. https://doi.org/10.1590/S0101-312220090 00300005

Pias, O. H.C., Damian, J. M., Alba, F., Giacomelli, A. H., Lowe, M. A., \& Testa, V. (2017). Germination and vigor of maize hybrids seeds submitted to water stress. Acta Iguazu, 6(1), 1-13.

Rajendran, R. A., Muthiah, A. R., Manickam, A., Shanmugasundaram, P., \& John, J. A. (2011). Indices of drought tolerance in sorghum (Sorghum bicolor L. Moench) genotypes at early stages of plant growth. Research Journal of Agriculture \& Biological Sciences, 7(1), 42-46.

Santarém, E. R., Almeida-Cortez, J. S., Silveira, T. S. A., \& Ferreira, A. G. (1996). Efeito do estresse hídrico na germinação e crescimento inicial de três espécies de leguminosas. Acta Botânica Brasileira, 10(2), 213-251. https://doi.org/10.1590/S0102-33061996000200002

Santos, O. O., Falcão, H., Antonino, A. C. D., Lima, J. R. S., Lustosa, B. M., \& Santos, M. G. (2014). Desempenho ecofisiológico de milho, sorgo e braquiária sob déficit hídrico e reidratação. Bragantia, 73(2), 203-212. https://doi.org/10.1590/brag.2014.018

Shahi, C., Vibhuti, K. B., \& Bargali, S. S. (2015). How seed size and water stress affect the seed germination and seedling growth in wheat varieties? Current Agriculture Research Journal, 3(1), 60-68. https://doi.org/ 10.12944/CARJ.3.1.08

Sikder, S., Hasan, M. A., \& Hossain, M. S. (2009). Germination characteristics and mobilization of seed reserves in maize varieties as influenced by temperature regimes. Journal of Agricultural and Rural Development, $7(1-2), 51-56$.

Silva, M. A., Jifon, J. L., Silva, J. A. G., \& Sharma, V. (2007). Use of physiological parameters as fast tools to screen for drought tolerance in sugarcane. Brazilian Journal of Plant Physiology, 19(3), 193-201. https://doi.org/10.1590/S1677-04202007000300003

Tabosa, J. N., Reis, O. V., Brito, A. R. M. B., Monteiro, M. C. D., Simplício, J. B., Oliveira, J. A. C., ... Oliveira, L. R. (2002). Comportamento de cultivares de sorgo forrageiro em diferentes ambientes agroecológicos dos Estados de Pernambuco e Alagoas. Revista Brasileira de Milho e Sorgo, 1(2), 47-58. https://doi.org/ 10.18512/1980-6477/rbms.v1n2p47-58

Taiz, L., Zeiger, E., Moller, I. M., \& Murphy, A. (2017). Fisiologia e desenvolvimento vegetal (6th ed., p. 888). Porto Alegre: Artmed.

Texeira, L. R., Braccini, A. L., Sperandio, D., Scapim, C. A., Schuster, I.; Viganó, J., \& Jaremtchuk, C. C. (2008). Avaliação de cultivares de soja quanto à tolerância ao estresse hídrico. Revista Ceres, 55(2), 194-202.

Tsago, Y., Andargie, M., \& Takele, A. (2014). In vitro selection of sorghum (Sorghum bicolor (L.) Moench) for polyethylene glycol (PEG) induced drought stress. Plant Science Today, 1(2), 62-68. https://doi.org/ 10.14719/pst.2014.1.2.14

Zhang, S., Hu, J., Zhang, Y., Xie, X. J., \& Allen, K. (2007). Seed priming with brassinolide improves lucerne (Medicago sativa L.) seed germination and seedling growth in relation to physiological changes under salinity stress. Australian Journal of Agricultural Research, 5(8), 811-815. https://doi.org/10.1071/ AR06253

Zhu, J., Kang, H., Tan, H., \& Xu, M. (2006). Effects of drought stresses induced by polyethylene glycol on germination of Pinus sylvestris var. mongolica seeds from natural and plantation forests on sandy land. Journal of Forest Research, 11(4), 319-328. https://doi.org/10.1007/s10310-006-0214-y

\section{Copyrights}

Copyright for this article is retained by the author(s), with first publication rights granted to the journal.

This is an open-access article distributed under the terms and conditions of the Creative Commons Attribution license (http://creativecommons.org/licenses/by/4.0/). 